\title{
Correction to: Transforming and changing urban centres: the experience of Sydney from 1981 to 2006
}

\author{
Alireza Salahi Moghadam ${ }^{1,2} \cdot$ Ali Soltani $^{2,3}$. \\ Bruno Parolin ${ }^{1}$
}

Published online: 22 December 2017

(C) Springer-Verlag GmbH Germany, part of Springer Nature 2017

\section{Correction to: Lett Spat Resour Sci https://doi.org/10.1007/s12076-017-0197-7}

In the original online publication, the name of Bruno Parolin had been omitted from the list of all authors.

The correct list of all authors must read "Alireza Salahi Moghadam, Ali Soltani and Bruno Parolin".

The original article has been corrected.

The original article can be found online at https://doi.org/10.1007/s12076-017-0197-7.

\footnotetext{
$\triangle$ Alireza Salahi Moghadam alireza.salahi@gmail.com

Ali Soltani soltani@shirazu.ac.ir

1 University of New South Wales, Sydney, Australia

2 Shiraz University, Shiraz, Iran

3 University of South Australia, Adelaide, Australia
} 